\title{
Distribution patterns of macroboring organisms on Tuléar reef flats (SW Madagascar)
}

\author{
Mireille Peyrot-Clausade ${ }^{1}$, Jean-François Brunel $^{2}$ \\ ${ }^{1}$ Centre d'Océanologie de Marseille U.A. 41, Rue de la Batterie-des-Lions, F-13007 Marseille, France \\ ${ }^{2} 3$ rue Fournier, F-91110 Clichy, France
}

\begin{abstract}
Macroboring organisms that were associated with 3 genera of corals (Acropora, Favia and Porites) principally in 3 different degrees of degradation and occurring at 13 different sites on a crossreef transect in the Tuléar reefs were studied. Thirty-one species were identified; the most abundant zoological group was sipunculids. Correspondence analysis was used to highlight successively the relationships between species and (1) sites, (2) genera and (3) degree of degradation. The distributional patterns of the macroborers were essentially associated with the physical factors of level of tide and flow energy. Calcareous algal coverage is followed by a decrease in abundance of individuals and species.
\end{abstract}

\section{INTRODUCTION}

Biological destruction of coral reefs is a complex phenomenon and several studies have been undertaken during the past 15 yr to quantify the role of borers and grazers in carbonate budgets of coral reefs. Hutchings (1986) gave an excellent review of these studies.

Samples for this study on macroboring organisms were collected in 1971 by J.-F. Brunel on the reef flats of Tuléar ( $\mathrm{SW}$ coast of Madagascar). A considerable amount of knowledge has been acquired on the structure of coral reef fauna assemblages of reefs in the western part of the Indian Ocean (Picard 1967, PeyrotClausade 1977, Montaggioni 1978, Pichon 1978, Thomassin 1978, Harmelin-Vivien 1979, Vasseur 1981, Faure 1982, Harmelin-Vivien et al. 1982).

In order to further our understanding of the functioning of these communities, it is necessary to consider bioerosion. This study attempts to define the different borer assemblages on the reef flats of Tuléar and the principal factors determining their distribution.

\section{METHODS}

Corals, primarily Porites, Acropora species and Favidae, were collected from the intertidal zone across different reef flats in the vicinity of Tulear. Three crossreef flats transects were surveyed: one in the north of Grand Récif near the small pools, a second in the south at Antseteke and a third on Songoritelo Reef (Fig. 1).
The different zones surveyed in each transect are illustrated in Fig. 2. A total of 323 dead corals were chiselled off and for each coral head the following data were recorded: locality, degree of degradation (1 - undamaged head unbored in cross section, 2 with traces of skeletal degradation, 3 - degradation throughout the skeleton).

In each zone, a minimum of 10 heads (each about $2 \mathrm{dm}^{3}$ ) of Porites, Acropora and Favidae were collected in each of the 3 degrees of skeletal degradation. The coral heads were then broken up into small pieces to remove the boring organisms. All invertebrates were studied except polychaetes (Clausade 1971) and sponges, which will be discussed elsewhere.

A correspondence analysis (Benzecri et al. 1973, Hill 1974, Naïm 1988) was performed, using an initial matrix including numerical averages of number of individuals for the 10 sample units (coral heads) of the same character (for example original habitat, species of coral, or degree of degradation) and the corresponding observations on boring organisms.

\section{RESULTS}

\section{Boring species}

Thirty-one species of macroorganisms were collected, belonging to sipunculans, molluscs, echinoids and cirripeds. Sipunculans, with 12 species, represented $74 \%$ of the total of 4374 boring individuals 


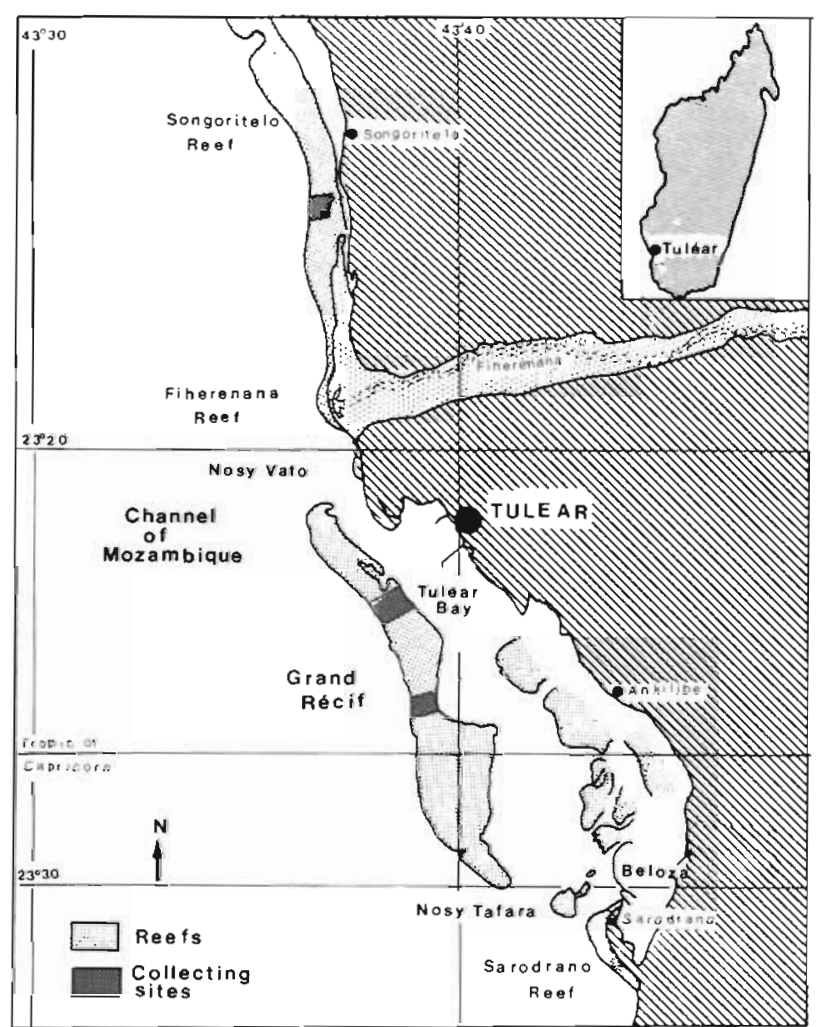

Fig. 1. Tuléar reefs, Madagascar, showing the 3 reef transects sampled

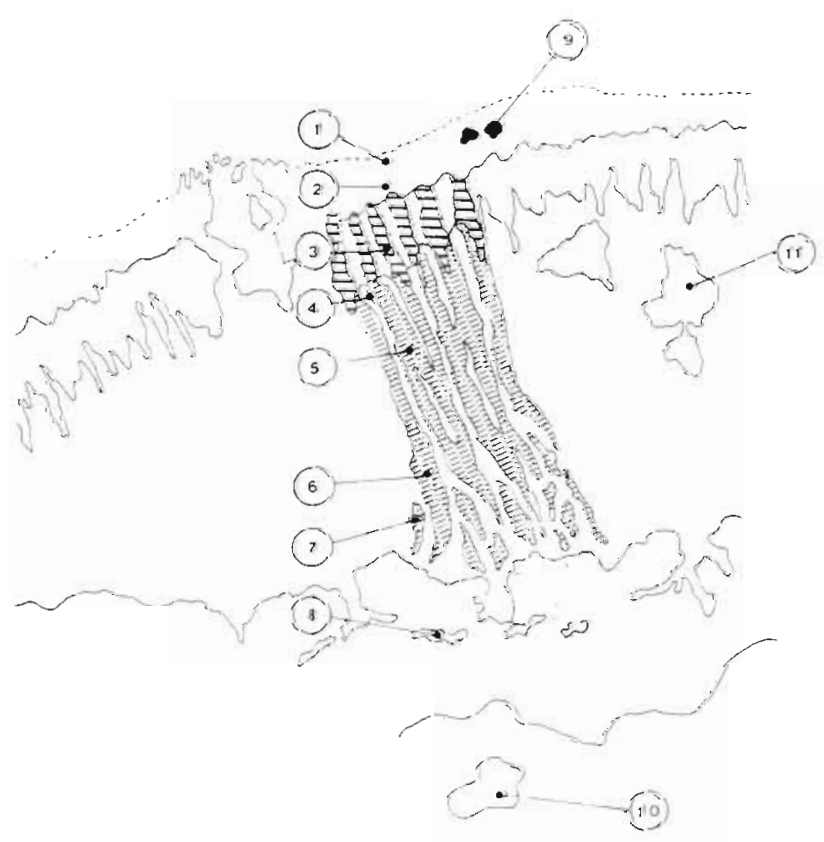

Fig. 2. Collecting sites across a typical reef. 1, outer front; 2 , upper reef glacis; 3, boulder tract; 4, residual pools; 5 , compact reef flat; 6 , reef flat with transverse stripe; 7 , reef flat with scattered coral growth; 8 , seagrass bed basin; 9 , megablocks; 10 , pinnacle of inner slope; 11 , small pools identified; molluscs, with 14 species, represented $20 \%$; echinoids, with 3 species, represented $3.5 \%$; and cirripeds, with 1 identified species, made up $2.5 \%$ of the total.

Relating total numbers of borers to substrate type (Table 1), it appears that the most bored substrata were those of the megablocks (328 ind./10 samples) (Battistini et al. 1975). Megablocks are blocks reaching sometimes several $\mathrm{m}^{3}$, torn off outer slopes by cyclones and carried onto outer reef flats. The least bored substratum was the reef platform behind the reef front. The Shannon-Weaver (1963) index indicated that the highest diversity occurred on the outer reef flat. The number of species varied on the reef flat from 12 in the small pool to 24 in the residual pools behind the boulder tract.

There is a relation between the degree of degradation (Table 2) of the coral head and the borer assemblages. The borers were most abundant in the most degraded skeletal substratum with 27 species (of the 31 collected in all) and 189 individuals per 10-sample unit (Fig. 3). Borers were least abundant in substratum covered with crustose calcareous algae (Table 2). In this habitat only 17 species and 45 ind./10 samples were found.

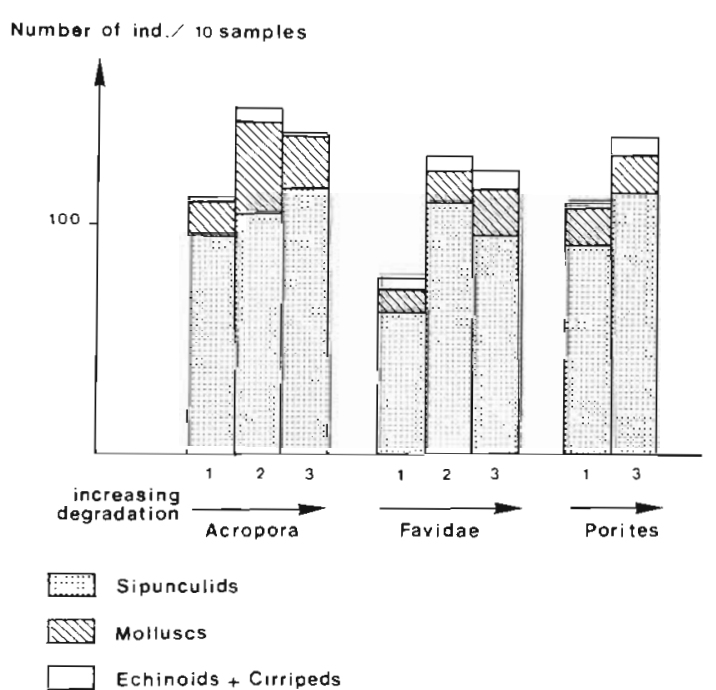

Fig. 3. Importance of the different borer groups as a function of increasing degradation of corals

If we consider the identity of the coral (Table 3 ), the average number of boring individuals in Acropora heads was about 110/10 samples, in Favidae 109/10 samples and in Porites 123/10 samples. The highest number of individuals occurred in colonies of Acropora with traces of skeletal degradation and the lowest in Acropora covered with calcareous algae. 
Table 1. Distribution of boring species according to the different structures of the reef for 10 samples. 1 , Outer front; 2 , upper reef glacis; 3, boulder tract; 4, residual pools; 5 , compact reef flat; 6 , reef flat with transverse stripes; 7 , reef flat with scattered coral growth; 8 , seagrass bed basin; 9 , megablocks; 10 , pinnacle of inner slope; 11 , small pools

\begin{tabular}{|c|c|c|c|c|c|c|c|c|c|c|c|}
\hline Species & 1 & 2 & 3 & 4 & 5 & 6 & 7 & 8 & 9 & 10 & 11 \\
\hline \multicolumn{12}{|l|}{ Sipunculids } \\
\hline Aspidosiphon elegans & - & - & - & 1.1 & - & - & - & - & - & 1.0 & - \\
\hline klunzingeri & - & - & - & - & 0.8 & 0.2 & 0.2 & - & - & - & - \\
\hline ochrus & 11.7 & 0.3 & 1.7 & 0.6 & 3.6 & 3.8 & 18.7 & 0.7 & 33.5 & - & - \\
\hline steenstrupii & 0.5 & 0.3 & 0.2 & - & 0.6 & 0.5 & 0.6 & - & - & - & - \\
\hline truncatus & - & - & - & 0.8 & - & - & - & - & - & - & - \\
\hline Cloeosiphon aspergillus & 22.2 & 8.8 & 120.0 & 61.7 & 74.0 & 78.0 & 73.5 & 114.8 & 153.5 & 39.0 & 31.0 \\
\hline Phascolosoma nigrescens & 0.9 & 1.6 & 1.0 & 0.3 & 3.0 & 1.4 & 0.8 & 11.0 & 0.8 & - & 2.0 \\
\hline pacificum & 9.1 & 2.5 & 5.7 & 3.1 & 2.6 & 2.9 & 0.8 & 0.7 & 10.4 & - & - \\
\hline perlucens & 1.7 & 3.2 & 3.6 & 1.9 & 6.6 & 7.1 & 2.9 & 22.4 & 6.2 & 3.0 & - \\
\hline scoplos & 5.3 & 0.9 & 6.2 & 1.4 & 4.7 & 0.5 & 3.3 & 4.1 & 4.6 & - & 6.0 \\
\hline Themiste lageniformis & 0.3 & 0.3 & - & - & - & 1.9 & 0.2 & 0.7 & -1 & - & - \\
\hline Sipunculid ind. & 1.3 & - & 0.7 & 1.1 & 0.2 & 1.4 & 0.2 & - & 3.5 & 5.0 & 1.0 \\
\hline \multicolumn{12}{|l|}{ Cirripeds } \\
\hline Lithotrya valentiana & 0.7 & - & 2.1 & - & 0.8 & - & - & 1.4 & 36.9 & - & - \\
\hline Cirriped ind. & - & - & - & - & 0.2 & - & - & - & - & - & - \\
\hline \multicolumn{12}{|l|}{ Molluscs } \\
\hline Acanthochiton zelandicus & 0.9 & - & 5.0 & 2.5 & - & - & - & - & 16.5 & - & - \\
\hline Cryptoplax striatus & 12.6 & - & 2.1 & 0.3 & 0.4 & - & - & - & 3.5 & - & - \\
\hline Dendropoma sp. & 0.2 & - & 0.5 & - & 2.8 & - & - & 0.3 & 35.8 & - & - \\
\hline Leptochonchus lamarckui & 2.1 & - & 3.1 & 0.3 & 1.1 & 1.4 & 0.6 & 0.3 & 4.2 & - & - \\
\hline Botula cinnamomea & - & 0.6 & 3.2 & 2.5 & 0.2 & - & 0.6 & 12.4 & 1.9 & 1.0 & - \\
\hline Cuspidaria sp. & - & - & 1.2 & 0.3 & - & - & - & 0.3 & 1.5 & 1.0 & - \\
\hline Gastrochaena cuneiformis & 0.7 & 0.3 & 2.4 & 2.8 & 0.2 & 1.0 & 5.2 & 12.4 & 2.3 & 4.0 & 5.0 \\
\hline sp. & 0.2 & - & 0.2 & 1.4 & 0.6 & - & - & 3.8 & - & - & - \\
\hline Gregariella coralliophila & 0.3 & 0.6 & 1.4 & 2.2 & 0.2 & 0.5 & - & - & 1.5 & 1.0 & - \\
\hline Lithophaga hanleyana & 2.1 & - & 6.4 & 17.0 & 1.0 & 1.4 & 6.0 & 18.7 & 1.9 & 3.0 & 2.0 \\
\hline lima & - & - & 1.7 & 2.2 & - & - & 0.6 & - & 3.1 & - & - \\
\hline malaccana & - & - & - & - & 0.2 & - & - & 2.1 & 0.4 & - & - \\
\hline nigra & 0.5 & 0.3 & 16.0 & 5.6 & - & - & 0.2 & 2.4 & 54 & 11.0 & 2.0 \\
\hline Petricola divergens & - & - & - & 0.6 & - & - & - & 1.0 & - & - & - \\
\hline \multicolumn{12}{|l|}{ Echinoids } \\
\hline Echinometra mathaei & 0.9 & 2.2 & - & 9.7 & 4.5 & 3.3 & 5.8 & 0.3 & - & 1.0 & 1.0 \\
\hline Echinostrephus mollaris & 0.2 & 2.5 & - & 8.9 & - & - & 0.2 & 0.3 & - & 1.0 & - \\
\hline Stomopneustes variolaris & - & - & 1.0 & 1.7 & 0.2 & - & - & - & - & - & 1.0 \\
\hline Total & 73.4 & 24.4 & 185.4 & 130.0 & 108.5 & 106.1 & 120.0 & 211.0 & 327.7 & 71.0 & 51.0 \\
\hline No. of species & 21 & 13 & 22 & 24 & 21 & 15 & 18 & 20 & 20 & 12 & 9 \\
\hline Shannon's diversity index & 3.12 & 2.97 & 2.63 & 2.95 & 2.04 & 1.73 & 2.06 & 2.44 & 2.75 & 2.45 & 1.98 \\
\hline
\end{tabular}

Sipunculids

This was the most abundant group of macroboring organisms (Fig. 4). The group represented at least $55 \%$ of the boring organisms of a biotope and at least $70 \%$ in each genus at all stages of degradation. Cloeosiphon aspergillus was found in all samples and represented $80 \%$ of the sipunculans collected. This species has previously been collected on the boulder tract of Tuléar Reef (Cutler \& Cutler 1979) and throughout western areas of the Indian Ocean. Aspidosiphon ochrus, a species described from the Indian Ocean by Cutler \& Cutler (1979), was the second most abundant sipuncu- lan. Its preferred habitat was the megablocks on the outer reef flat. Phascolosoma perlucens, P. scolops and $P$. nigrescens were present in all the flat biotopes, and on all substrata, but varying in abundance. $P$. perlucens was considered to be rare in the Indian Ocean by Cutler \& Cutler (1979). In this survey 175 specimens were collected, most of them from coral heads in depressions in seagrass beds. Rice \& MacIntyre (1982) found this species in shallow water on the reef crest and the high relief spur and grooves present on Caribbean reefs. The other 5 species of sipunculans together made up less than $2 \%$ of the total number of sipunculans. Themiste lageniformis was most abundant in 
Table 2. Distribution of boring species according to degree of degradation of substratum on Tuléar reef flats for 10 samples. 1. Dead head undamaged; 2 , traces of skeletal degradation; 3 , degradation throughout the skeleton; 4 , very altered substrate; 5, heads covered with crustose calcareous algae

\begin{tabular}{|c|c|c|c|c|c|}
\hline Species & 1 & 2 & 3 & 4 & 5 \\
\hline \multicolumn{6}{|l|}{ Sipunculids } \\
\hline Aspidosiphon elegans & 0.4 & - & - & 0.9 & 0.2 \\
\hline klunzingeri & - & - & 0.8 & - & - \\
\hline ochrus & 4.0 & 15.1 & 2.5 & 4.1 & 6.1 \\
\hline steenstrupii & 0.5 & 0.5 & 0.4 & - & - \\
\hline truncatus & - & 0.2 & 0.6 & - & 0.5 \\
\hline Cloeosiphon aspergillus & 69.6 & 74.7 & 87.3 & 105.3 & 15.9 \\
\hline Phascolosoma nigrescens & 0.6 & 0.7 & 3.3 & 3.8 & 3.2 \\
\hline pacificum & 2.4 & 6.1 & 2.5 & 3.4 & 3.9 \\
\hline perlucens & 3.4 & 5.3 & 6.5 & 7.5 & 7.7 \\
\hline scoplos & 3.1 & 3.7 & 5.0 & 4.8 & 2.7 \\
\hline Themiste lageniformis & 0.3 & 0.7 & 0.6 & 0.3 & - \\
\hline Sipunculid ind. & 0.6 & 1.9 & 1.5 & 1.6 & - \\
\hline \multicolumn{6}{|l|}{ Cirripeds } \\
\hline Lithotrya valentiana & 0.6 & 1.4 & - & 7.2 & - \\
\hline Cirriped ind. & 0.1 & - & - & - & - \\
\hline \multicolumn{6}{|l|}{ Molluscs } \\
\hline Acanthochiton zelandicus & 0.5 & 1.9 & 0.2 & 2.2 & - \\
\hline Cryptoplax striatus & 2.3 & - & 0.4 & 2.8 & - \\
\hline Dendropoma sp. & 1.6 & 1.2 & - & 0.3 & - \\
\hline Leptochonchus lamarckii & 0.6 & 2.3 & 1.5 & 0.6 & 0.2 \\
\hline Botula cinnamomea & 0.6 & 1.6 & 3.5 & 5.6 & 0.7 \\
\hline Cuspidaria sp. & - & 0.9 & - & 0.6 & - \\
\hline Gastrochaena cuneiformis & 1.9 & 5.6 & 2.3 & 5.3 & 0.7 \\
\hline $5 p$ & - & 1.2 & 0.8 & 1.3 & 0.5 \\
\hline Gregariella coralliophila & 0.4 & 0.9 & 1.4 & 0.3 & 0.2 \\
\hline Lithophaga hanleyana & 4.0 & 11.2 & 6.2 & 9.1 & 0.7 \\
\hline lima & 0.6 & 1.2 & 0.9 & 1.9 & 1.1 \\
\hline malaccana & - & 0.5 & 0.2 & 0.3 & - \\
\hline nigra & 2.9 & 3.5 & 2.3 & 7.8 & 0.5 \\
\hline Petricola divergens & - & - & - & 1.3 & - \\
\hline \multicolumn{6}{|l|}{ Echinoids } \\
\hline Echinometra mathaei & 0.5 & 2.3 & 2.9 & 1.3 & 0.7 \\
\hline Echinostrephus mollaris & 0.9 & 0.9 & - & 9.1 & - \\
\hline Stomopneustes variolaris & 0.3 & 0.7 & - & - & - \\
\hline Total & 1027 & 143.9 & 130.2 & 189.3 & 45.5 \\
\hline No. of species & 25 & 25 & 23 & 27 & 17 \\
\hline
\end{tabular}

Favidae heads collected from the inner reef flat, Aspidosiphon klunzingeri occurred in Acropora and Porites damaged heads, while Aspidosiphon elegans and $A$. truncatus were preferentially located in the residual pools present behind the boulder tract. Residual pools are small dips located behind the boulder tract which remain filled with seawater during low tides (Battistini et al. 1975).

The greatest diversity of sipunculans occurred on the inner reef flat with 9 species. The lowest diversity occurred in the megablocks which was also the biotope most inhabited by sipunculans. Sipunculan abundances were similar in the 3 corals with the same degree of

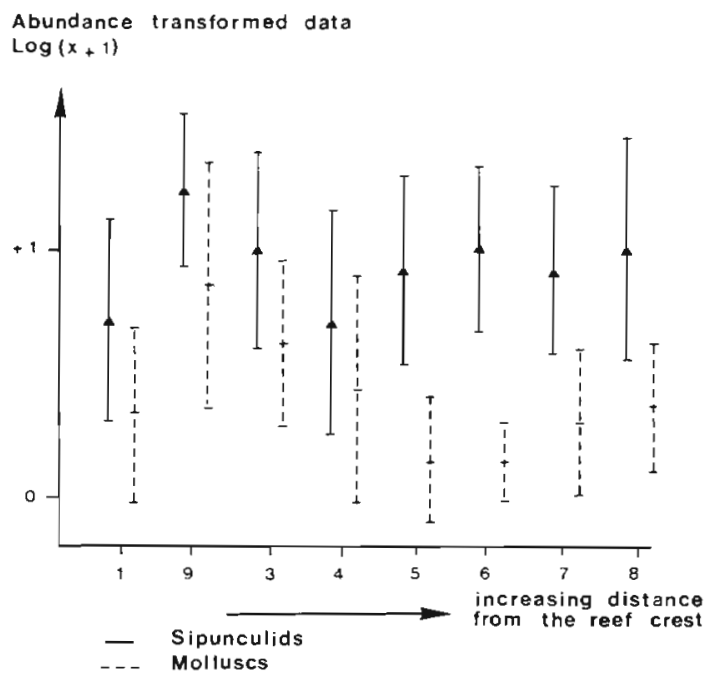

Fig. 4. Means and standard deviations of abundance per 10 samples. Transformed data for sipunculids and molluscs as a function of distance from reef crest. See Fig. 2 for explanation of Sites 1 to 9

degradation, e.g. in Acropora with trace of degradation, 107 sipunculans per 10 heads, in Favidae also 107 individuals and in Porites 113 individuals.

\section{Cirripeds}

The rock boring barnacle Lithotrya valentiana was found in hard substrata at the medio-littoral level, i.e. in the boulder tract and principally in the megablocks where they constituted $10 \%$ of the borer assemblage. The preferred habitat was very degraded coral Favidae heads (37 ind./10 samples).

Molluscs

Boring molluscs constituted $20 \%$ of the organisms collected in this survey, and included Amphineura, Bivalvia and Gastropoda. Fig. 4 shows a decrease in mean numbers of this group with increasing distance from the reef crest.

Amphineura. On the reef flat 2 species were present, Cryptoplax striatus and Acanthochiton zelandicus. $C$. striatus was most abundant in samples from the outer reef flat with fewer individuals present on the boulder tract and the megablocks. A. zelandicus occurred in medio-littoral hard substratum formations such as megablocks and boulder tracts, especially in heads of Acropora and Favidae.

Gastropoda. An unidentified species of Dendropoma was most abundant in the megablocks and this rep- 
Table 3. Distribution of boring species according to coral genus and their degradation degree on Tuléar reef flats for 10 samples. 1 , Dead coral undamaged; 2 , traces of skeletal degradation; 3, degradation throughout the skeleton; 4, Acropora covered by concretions; 5, branched Acropora

\begin{tabular}{|c|c|c|c|c|c|c|c|c|c|c|}
\hline \multirow[t]{2}{*}{ Species } & \multicolumn{5}{|c|}{ Acropora } & \multicolumn{3}{|c|}{ Favidae } & \multicolumn{2}{|c|}{ Porites } \\
\hline & 1 & 2 & 3 & 4 & 5 & 1 & 2 & 3 & 1 & 3 \\
\hline \multicolumn{11}{|l|}{ Sipunculids } \\
\hline Aspidosiphon elegans & 0.9 & - & - & - & - & - & - & - & - & - \\
\hline klunzingeri & - & - & 1.4 & - & - & - & - & - & - & 0.7 \\
\hline ochrus & 0.6 & 15.0 & 2.4 & 4.7 & 0.8 & 2.0 & 6.8 & 2.9 & 9.6 & 2.1 \\
\hline steenstrupii & 0.3 & 0.5 & - & 0.3 & 0.8 & 1.0 & - & - & 0.4 & - \\
\hline truncatus & 81.8 & - & 0.5 & - & - & - & - & - & - & - \\
\hline Cloeosiphon aspergillus & 0.9 & 77.5 & 98.6 & 22.7 & 59.2 & 47.0 & 74.3 & 69.4 & 71.4 & 92.1 \\
\hline Phascolosoma nigrescens & 3.9 & 0.5 & 3.3 & 0.7 & 1.7 & 0.5 & 1.3 & 2.3 & 0.4 & 4.3 \\
\hline pacificum & 2.4 & 6.5 & 1.9 & 5.0 & 2.5 & 3.0 & 8.1 & 5.3 & - & - \\
\hline perlucens & 4.2 & 5.0 & 4.3 & 2.3 & 5.8 & 5.5 & 8.1 & 10.0 & 3.0 & 5.7 \\
\hline scoplos & - & 2.5 & 3.8 & 3.7 & 2.5 & 1.0 & 6.2 & 5.3 & 3.3 & 6.4 \\
\hline Themistre lageniformis & - & - & - & - & - & 0.5 & 1.8 & 0.6 & 0.4 & - \\
\hline Sipunculid ind. & & - & 1.0 & 1.0 & - & 1.0 & 3.8 & 1.8 & 1.1 & 2.1 \\
\hline \multicolumn{11}{|l|}{ Cirripeds } \\
\hline Lithotrya valentiana & 0.6 & - & - & 0.3 & - & 1.5 & 1.3 & - & - & - \\
\hline Cirriped ind. & 0.3 & - & - & - & - & - & - & - & - & - \\
\hline \multicolumn{11}{|l|}{ Molluscs } \\
\hline Acanthochiton zelandicus & 1.2 & 4.0 & 0.5 & 0.7 & - & - & - & - & - & - \\
\hline Cryptoplax striatus & 3.6 & - & - & 3.3 & - & 3.0 & - & 1.8 & - & - \\
\hline Dendropoma sp. & - & - & - & - & - & 0.5 & 0.6 & - & 3.7 & - \\
\hline Leptochonchus lamarckii & - & 1.0 & - & - & 7.5 & 2.5 & 4.8 & 4.7 & - & - \\
\hline Botula cinnamomea & 0.6 & 2.5 & 1.4 & 1.0 & 0.8 & - & - & 5.3 & 1.1 & 4.3 \\
\hline Cuspidaria sp. & - & 0.5 & - & - & - & - & 1.3 & - & - & - \\
\hline Gastrochaena cuneiformis & 1.2 & 2.0 & 1.4 & 1.7 & & 0.5 & 0.6 & 1.8 & 3.7 & 5.0 \\
\hline ind. & - & 2.5 & - & - & 0.8 & - & - & 1.8 & - & 0.7 \\
\hline Gregariella coralliophila & 0.9 & 1.5 & 2.9 & - & - & - & 0.6 & 0.6 & - & - \\
\hline Lithophaga hanleyana & 3.6 & 16.0 & 10.5 & 3.0 & 1.7 & 1.0 & 4.8 & 1.7 & 6.7 & 4.3 \\
\hline lima & 1.2 & 2.0 & 1.9 & - & - & - & - & - & 0.4 & 0.7 \\
\hline malaccana & - & 0.5 & - & - & - & - & - & 0.6 & - & - \\
\hline nigra & 3.6 & 6.0 & 3.8 & 1.3 & - & 4.5 & 1.8 & 2.3 & 0.7 & - \\
\hline Petricola divergens & - & - & - & - & - & - & - & - & - & 0.7 \\
\hline \multicolumn{11}{|l|}{ Echinoids } \\
\hline Echinometra mathaei & 0.3 & 2.5 & 0.5 & - & 9.2 & 0.5 & 1.8 & 2.9 & 1.8 & - \\
\hline Echinostrephus mollaris & 0.3 & 2.0 & - & - & 0.8 & - & - & - & - & 1.4 \\
\hline Stomopneustes variolaris & - & 1.0 & - & - & - & 1.0 & - & - & 0.4 & 6.4 \\
\hline Total & 112.4 & 151.5 & 141.1 & 51.7 & 94.1 & 76.5 & 128.0 & 121.2 & 108.1 & 137.6 \\
\hline No. of species & 20 & 21 & 18 & 15 & 13 & 18 & 17 & 18 & 16 & 15 \\
\hline
\end{tabular}

resented about $10 \%$ of their boring population. It was most abundant in Porites.

Another species of boring gastropod occurred in this area, Leptoconchus lamarckii, which is also known to bore in living corals (Soliman 1969, Scott 1980). It was not abundant but occurred over the whole reef flat, especially in branched Acropora and in the Favidae.

Bivalvia. A total of 622 specimens belonging to 10 species were collected. The majority of the bivalves were lithophagines of which 2 species, Lithophaga nigra and $L$. hanleyana, represented $50 \%$ of the individuals. L. nigra, already reported by Arnaud \& Thomassin (1986), occurred preferentially on the boul- der tract, small pools, residual pools and megablocks. It was absent only from branched Acropora and very damaged Porites. L. hanleyana occurred in all the biotopes and all 3 corals regardless of extent of degradation. It was the most abundant bivalve species and preferred biotopes almost constantly submerged, such as seagrass bed depressions and residual pools. Botula cinnamomea showed a marked degree of specialization: it mostly occurred in very degraded substrata, particularly of the genus Porites, in seagrass beds and residual pools. Gastrochaena cuneiformis showed no preference for any particular type of biotope. It was present in all the coral genera regardless of degrada- 
tion, except in branched Acropora. It was particularly abundant in Porites on the inner reef flat, small pools and pinnacles of the inner slope. Gregariella coralliophila was less abundant but had a wide distribution. The remaining 5 species, Lithophaga malaccana, Petricola divergens, Cuspidaria sp., Gastrochaena sp. and Lithophaga lima represented less than $12 \%$ of the bivalve assemblage; L. Lima is known to be a borer of living corals (Wilson 1979).

\section{Echinoids}

Echinoids play an important role in the biological destructions of coral reefs by surface grazing (Bromley 1978, Russo 1980, Bak 1985, Hutchings 1986). This group includes some of the principal grazers of substrates covered by encrusting coralline algae, filamentous algae and blue-green algae.

Three species (about 170 individuals) were recorded in this survey: Echinometra mathaei, Echinostrephus mollaris and Stomopneustes variolaris. E. mathaei was the most abundant, particularly in the residual pools and on the inner reef flat. E. mollaris also occurred in residual pools and in small pools. If the nature of substrata is considered, it clearly appears that $E$. mathaei, which was found in all corals was most abundant in branched Acropora, and $S$. variolaris in heavily bored Porites. E. mollaris seemed to prefer bored Acropora.

\section{Spatial distribution of borers}

Distribution of the 4 groups of boring organisms in relation to reef flat structures is shown in Table 4 and Fig. 5 .

Correspondence analysis is used to extract information on the relationship between species and reef structure, and bioeroder species and the different corals, at various stages of degradation.

\section{Macroboring species and reef structures}

The first principal component analysis was performed on a matrix data consisting of 31 observations (borer species) and 11 variables (reef structures). All the samples are classified according to their original habitats (outer front, boulder tract, etc.) (Fig. 6)

The first 3 factors of this analysis explain $65.9 \%$ of the total variance. Factor 1 , extracting $33.1 \%$ of the variance, is defined by the variable megablocks opposed to residual pools and seagrass bed hollows. Factor 2, extracting $18.3 \%$ of the variance, is defined

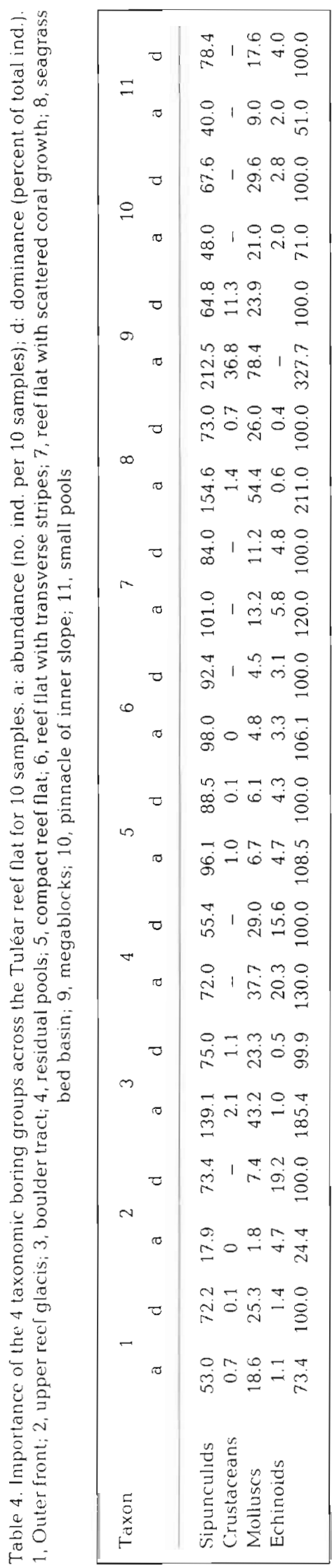




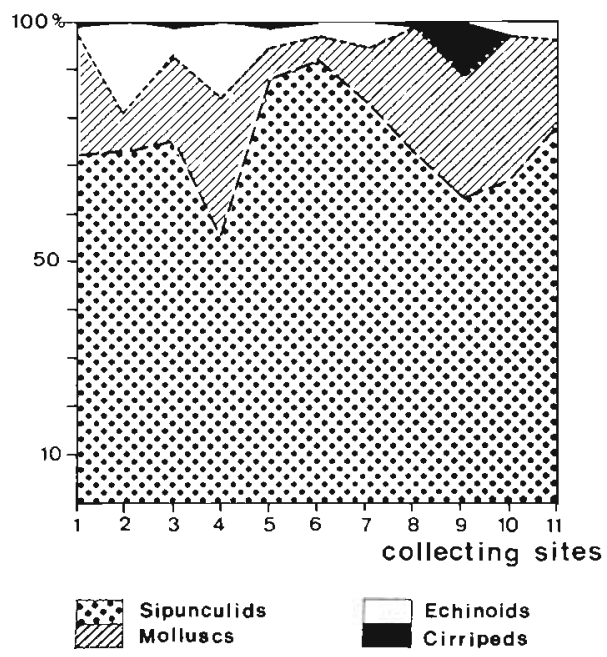

Fig. 5. Distribution of the 4 taxonomic groups of borer organisms on Tulear reef flats

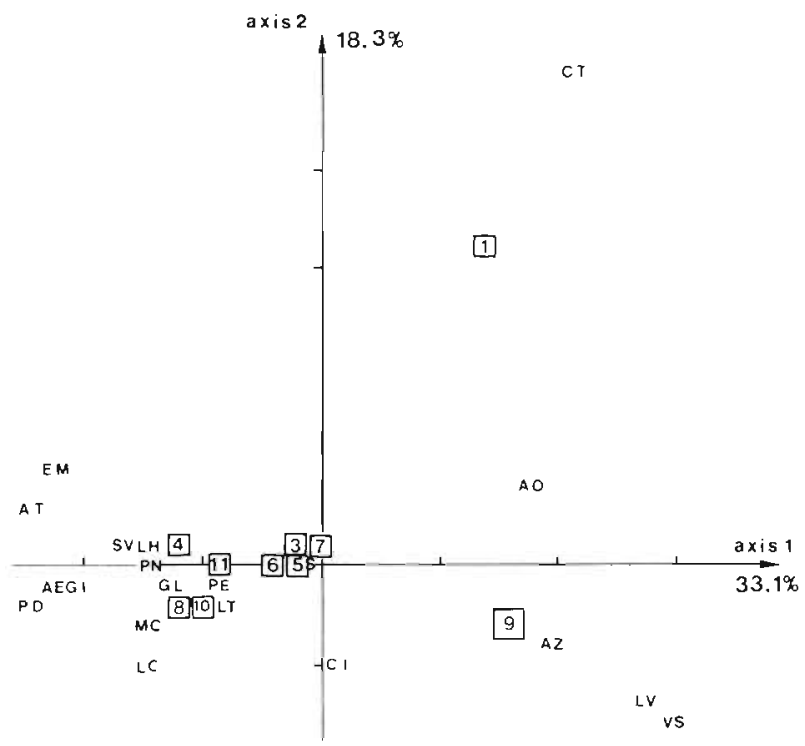

Fig. 6. Correspondence factor analysis. Plot of the 2 first factor axes. Observations are borer species: AO, Aspidosiphon ochrus; PE, Phascolosoma perlucens; LV, Lithothrya valentiana; AZ, Acanthochiton zelandicus; CT, Cryptoplax striatus; VS, Dendropoma sp.; MC, Botulina cinnamomea; GL, Gastrochaenia cuneiformis; GI Gastrochaenia sp.; LH, Lithophaga hanleyana; PD, Petricola divergens; SV, Stomopneustes variolaris. Variables are the 11 reef habitats (cf. Fig. 2)

by the variable outer front, and Factor 3, extracting $14.5 \%$ of the variance, is controlled by the small pools.

This first analysis allows us to assign Axis 1 to an emersion factor. The megablocks located at the positive extremity of this axis contain the biota which emerge earlier and for longer times, with a high degree of drying up of cavities, and at the opposite extremity residual pools and seagrass bed hollows contain biota nearly always submerged. Axis 2 represents the surf action on the front reef. Axis 3 can be assigned to sedimentation which increases from the front of the reef to the seagrass bed and inner slope (Vasseur 1981). This sedimentation is also very important in the small pools.

Arrangement of the species points within the 3 dimensions forms 3 distinct groups. The first includes species with a high absolute contribution around Stn 9 (megablocks) (Fig. 2). These species are: Lithotrya valentiana (barnacle), Aspidosiphon ochrus, Acanthochiton zelandicus and Dendropoma sp.

The second group of species is projected near Stn 8 (seagrass bed) and Stn 4 (residual pools) and is formed by Gastrochaena sp., Botula cinnamomea, Petricola divergens, Lithophaga hanleyana and Phascalosoma perlucens. The amphineuran Cryptoplax striatus is projected near Stn 1 (outer front).

A similar correspondence analysis was performed using the barycentre (center of gravity of a set of vectors) corresponding to the borer assemblage for each habitat and each of the 3 reef sectors studied. The data matrix included 352 observations (22 barycentres were calculated) and 31 variables within the factor space (1.2) and (1.3). Five groups are clearly distinguished (Fig. 7). Group A includes the 2 megablock barycentres and the 3 species Dendropoma sp., Lithotrya valentiana and Acanthochiton zelandicus. Group B comprises the 4 barycentres of the outer reef flat and the species Cryptoplax striatus. Group C concerns the residual pools barycentres and the 3 echinoids Echinometra mathaei, Stomopneustes variolaris, Echinostephus mollaris plus the sipunculids Aspidosiphon elegans and $A$. truncatus. Group D shows the association between the 3 seagrass bed barycentres and Petricola divergens and Gastrochaena cuneiformis. Group $E$ is formed by the 3 boulder tract barycentres and Cloeosiphon aspergillus.

\section{Macroboring species and corals}

The distributions of macroborers in the 3 genera of corals with various degrees of degradation are detailed in Table 3 .

Five different categories of Acropora were studied: Acropora with small branches in 3 different degrees of degradation, Acropora covered by algal encrustations, and large branched Acropora. This last category contained the least diverse fauna with only 13 species, characterized by Leptoconchus lamarckii. Acropora heavily encrusted contained 15 species with a density 


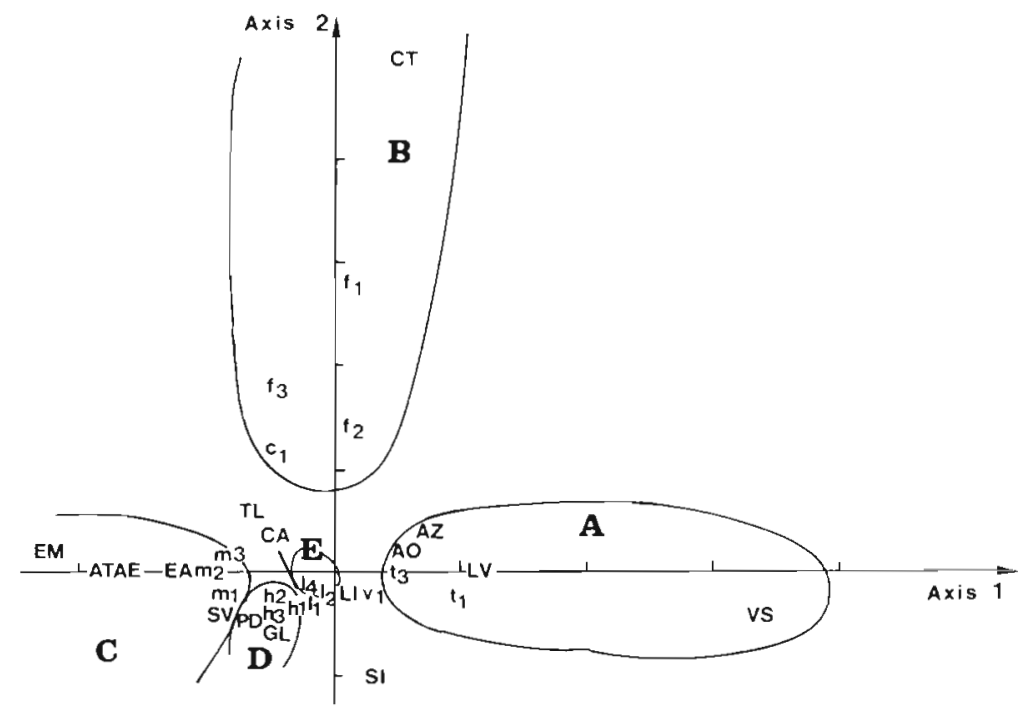

Fig. 7. Correspondence factor analysis. Plot of the 2 factor axes. Projections of barycentres corresponding to borer assemblage for each habitat and each of the 3 reef sectors studied. $f_{1}, f_{2}, f_{3}, c_{1}$ barycentres of outer front; $\mathrm{m}_{1}, \mathrm{~m}_{2}, \mathrm{~m}_{3}$ : barycentres of residual pools; $h_{1}, h_{2}, h_{3}$ : barycentres of seagrass bed basins; $i_{1}, i_{2}, i_{3}$ : barycentres of boulder tracts; $t_{1}, t_{3}$ : barycentres of megablocks. Species other than those in Fig. 6: AE, Aspidosiphon elegans; AT, Aspidosiphon truncatus; CA, Cloeosiphon aspergillus; TL, Themiste lageniformis; EA, Echinometra mathaei; EM Echinostrephus mollaris. Groups A to E are explained in the text of 51 ind./10 samples. This is the lowest density recorded. In the other 3 categories the number of species varied between 18 and 21 with a maximum number of individuals (15 ind./10 samples) occurring in coral with trace skeletal degradation.

In Favidae, the number of macroborer species was similar regardless of degradation of the skeleton (between 17 and 18 species) but for Acropora and Porites, the density of macroborers varied according to the level of degradation with the least degraded skeleton having the lowest number of borers.

Porites exhibited the least diversified substrate. Only 2 degrees of degradation were recognized: undamaged heads and degradation throughout the skeleton.

In the correspondence analysis produced from the matrix data including 10 observations $(3$ corals at different degrees of degradation) and 31 variables (species of macroborer), the first 3 factors extract $59 \%$ of the total variance (Fig. 8). Factor 1 extracting $24.3 \%$ of the variance is largely controlled by the opposition between large branched Acropora (absolute contribution, $\mathrm{AC}=0.52$ ) and slightly damaged Acropora ( $\mathrm{AC}=$ $0.13)$. Factor 2 extracting $18.9 \%$ of the variance depends upon damaged Porites $(\mathrm{AC}=0.53$ ) opposed to encrusted Acropora ( $\mathrm{AC}=0.13$ ). Factor 3 extracting $15.8 \%$ of the variance is defined by undamaged Favidae and Acropora. Analysis of proximities between the variables and the observations provides an explanation of the relationships between the corals with their degrees of degradation, and the macroboring species. Samples of large branched Acropora are characterized by Leptoconchus lamarckii and Echinometra mathaei, very damaged Porites is characterized by Stomopneustes variolaris and encrusted

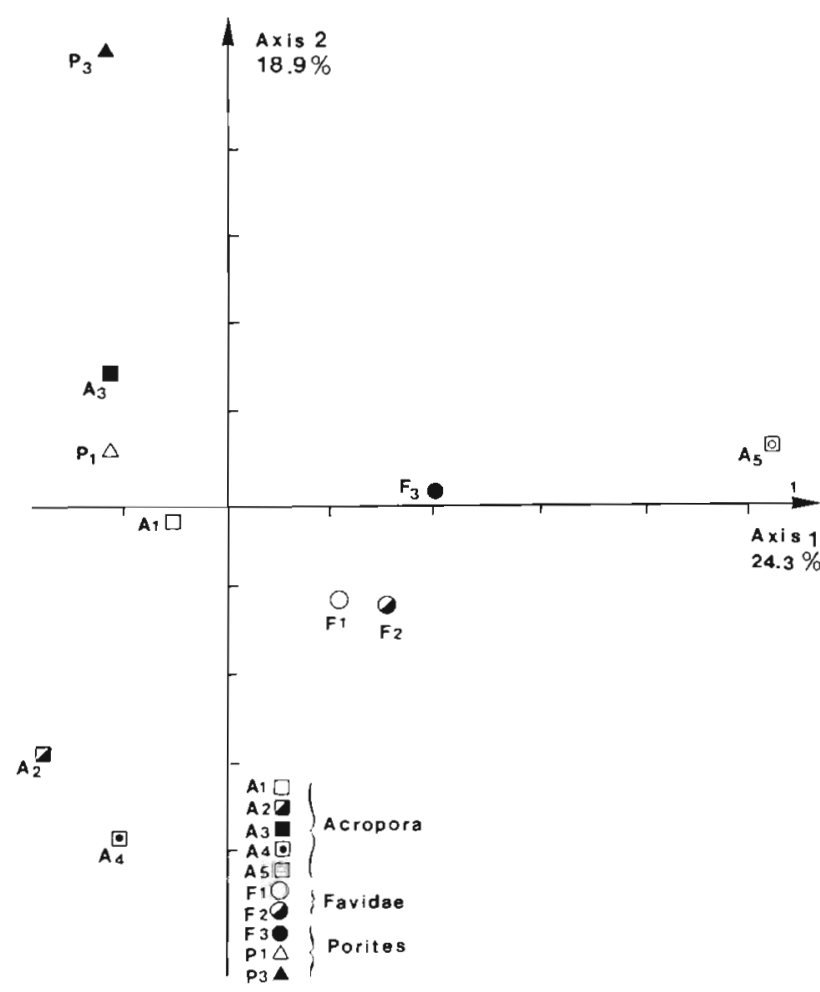

Fig. 8. Correspondence factor analysis. Plot of the 2 first axes. Samples considered according to coral genus or family and their degree of degradation. $A_{1}$, Acropora undamaged; $A_{2}$, Acropora with traces of skeletal degradation; $\mathrm{A}_{3}$. Acropora with degradation throughout the skeleton; $A_{4}$, Acropora covered by concretions; $A_{5}$, branched Acropora; $F_{1}$, Favidae with traces of skeletal degradation; $F_{2}$, Favidae with degradation throughout the skeleton; $P_{1}$ Porites with traces of skeletal degradation; $P_{3}$, with degradation throughout the skeleton 
Acropora is associated with Phascolosoma pacificum. Cryptoplax striatus and Lithotrya valentiana are projected near the undamaged heads of Acropora and Favidae.

A further correspondence analysis was performed utilising the barycentre corresponding to the borer assemblage for each coral and for each degree of degradation according to each original habitat. The results (Fig. 9) show that Axis 1 depends upon barycentres of very damaged Porites and slightly damaged Acropora of megablocks. Axis 2 is defined by the barycentres of little damaged Acropora and undamaged Acropora of the outer reef flat. From the spatial ordination of the barycentres of variables and observations within the 2 bidimensional spaces, 4 groups can be distinguished which are the same 4 groups defined in considering only the original structure of the samples, i.e. Group A includes samples of megablocks, Group B those of the outer reef flats, Group $C$ samples of residual pools and Group D those of the seagrass beds. Two barycentres of variables are closely linked to Groups A and C: near A is the barycentre of cirripeds and near $C$ that of echinoids. This analysis shows that the degree of damage is not an important factor for the distribution of macroboring organisms. If we now con- sider only the barycentres of the 3 corals in terms of their original structures, we obtain (Fig. 10) as before a first axis dependent on Acropora and Porites of megablocks, a second axis defined by Acropora and Favidae of outer reef flats and the same 4 groups of points in the 2 bidimensional spaces. Thus all these different correspondence analyses indicate that on the reef flats of Tulear, the distribution of the macroborer organisms is associated with 3 major environmental factors: (1) aerial exposure time corresponding to a medio-littoral level, represented by the megablocks with Lithotrya valentiana, Acantochiton zelandicus and Dendropoma sp.; (2) strong wave action which characterizes the habitats in the outer reef flat; Cryptoplax striatus is the characteristic species of this zone; (3) very short periods of aerial exposure found in the residual pools and the seagrass bed; these biotopes are the preferred habitat of the urchins and of Lithophaga hanleyana.

It appears that the diversity and density of boring communities are correlated with the cover of algae rather than by the coral species, and also that the degree of branching is very important.

The degree of damage does not affect community composition, but the number of individuals is higher in damaged heads

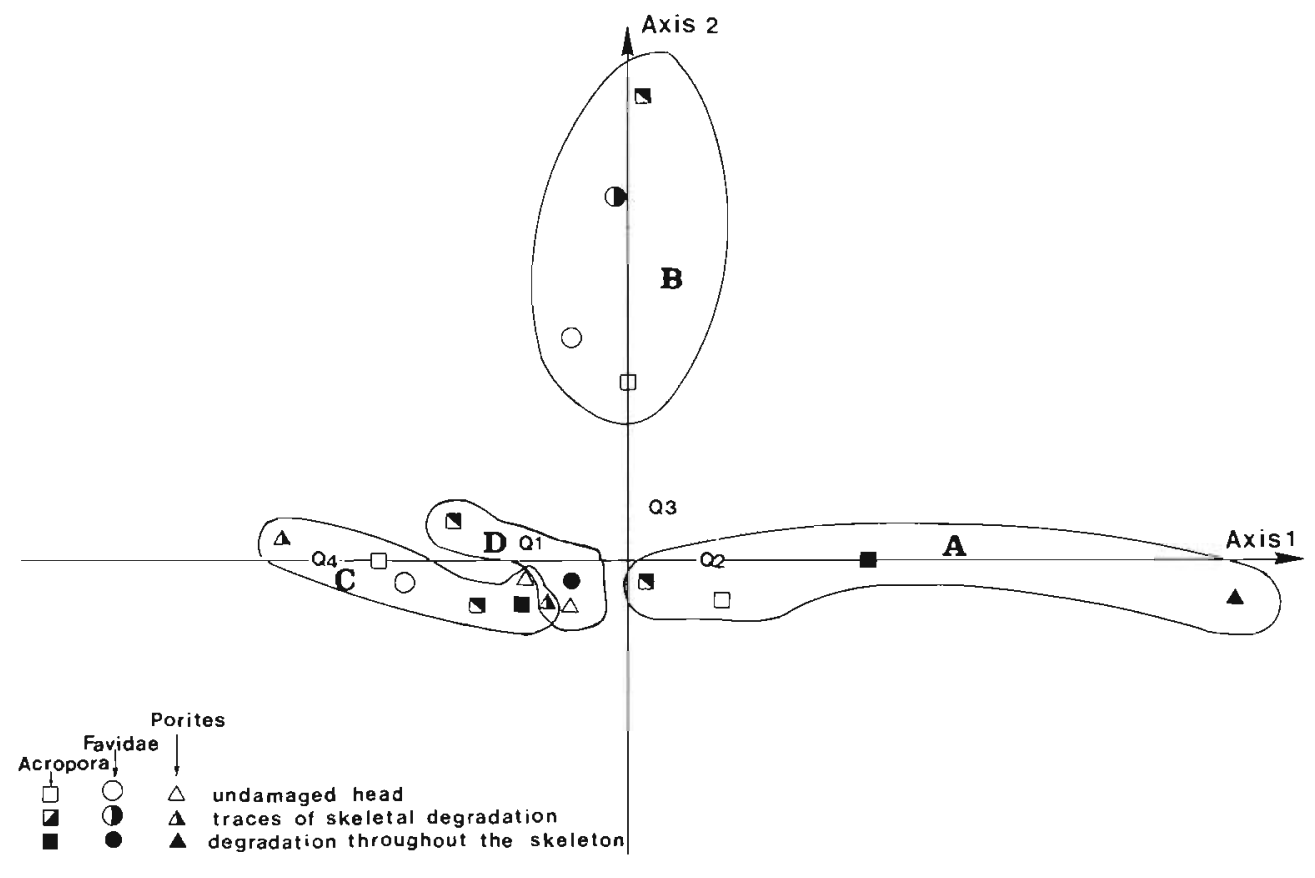

Fig. 9. Correspondence factor analysis. Plot of the 2 first factor axes. Barycentres of variables (taxonomic borer groups) and of observations according to coral genus or family and degree of degradation. A, megablock group; B, outer reef flat group; C, residual pool group; $D$, seagrass bed group. $Q_{1}$, barycentre of sipunculids; $Q_{2}$, barycentre of cirripeds; $Q_{3}$, barycentre of molluscs; $Q_{4}$, barycentre of echinoids 


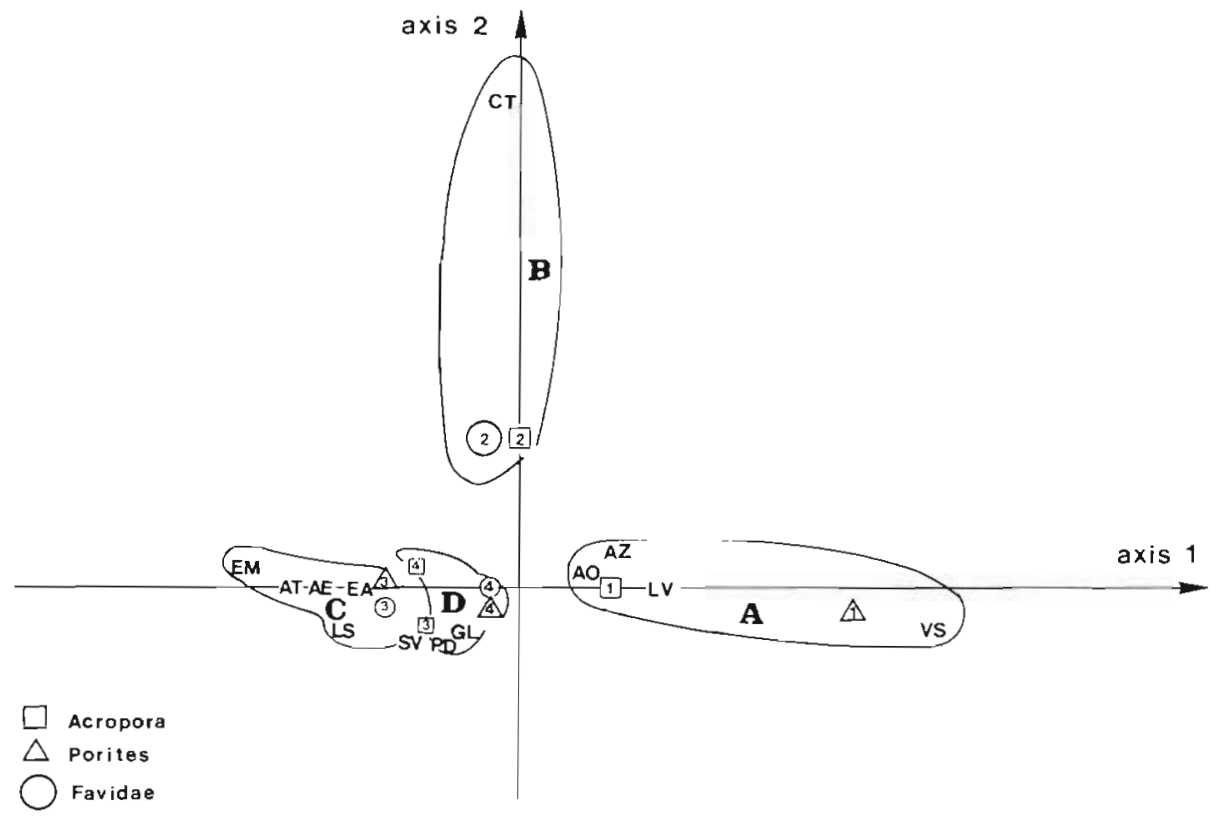

Fig. 10. Correspondence factor analysis. Plot of the 2 first factor axes. Projections of barycentres of observations according to coral genus or family and their original habitats and of variables borer species. A, megablock group; B, outer reef flat group; $C$, residual pool group; $D$, seagrass bed group. 1, corals corring from the megablock; 2 , from outer reef flat; 3 , from residual pool; 4, from seagrass bed

\section{DISCUSSION AND CONCLUSIONS}

This survey shows that the boring fauna of Acropora, Porites and Favidae appears relatively homogeneous across the reef flats of Tuléar.

Sipunculans were the most abundant borers with a maximum number of individuals occuring in the megablock biotope (about 15 ind $\mathrm{dm}^{-3}$ ). This maximal density is just lower than that of boring polychaetes found in cavitary blocks: 20 ind. $\mathrm{dm}^{-3}$. The dominant boring polychaete was the eunicid Lysidice collaris (Clausade 1971). Eunicidae was considered by Crossland (1903) and by Ebbs (1966) to be the major coraldestroying family among polychaetes. The only detailed study of sipunculan distribution across a reef is that of Rice \& MacIntyre (1982) on Carrie Bay off Belize (Caribbean). They found that the greatest concentration and the greatest diversity occurred on the reef crest. They suggested that the distribution of species may be determined more by physical factors associated with locality than by the type of coral skeleton. Our data tend to confirm this view. On Tuléar reefs the distribution of sipunculans relative to the degree of degradation shows that abundance increases with an increase in coral degradation and decreases on substrata covered by sand or by encrustation. Our results also corroborate those of Davies \& Hutchings (1983) who showed that sipunculans do not colonize newly available coral substrate. It can be seen in Table 2 that sipunculans are less abundant in new dead heads (undamaged) than in more damaged substrate. Although abundant, sipunculans are not considered very active agents of bioerosion. Highsmith et al. (1983) indicated that only $0.6 \%$ of boring in colonies of Montastrea annularis on Belize Barrier Reef was due to sipunculans.

The other very important boring group on Tuléar reef flats is the molluscs. Biotopes in which Bivalvia are very abundant are found on the boulder tract and in residual pools, and the most preferred sites are the blocks within the seagrass beds, which are nearly always immersed. Coral-boring bivalves have been very well studied (Morton 1983). Species found in great abundance are known to bore into dead corals, except for Lithophaga hanleyana which is cited by Scott (1980) as boring into living coral species; however, Wilson (1979) and Kleeman (1984) collected it on dead substrata from beach rock, boulder tract and Porites of Heron Island (Great Barrier Reef). Morton (1983), in his review of coral-associated bivalves of the Indo-Pacific, discussed the great variability of results concerning the coral host of the different species of Lithophaga.

Lithophaga species in Tulear reef flat did not show a clear preference for a particular genus of coral or degree of degradation. Gastrochaenidae are more abundant in Porites. On Hong Kong reefs, Scott (1980) did not find Gastrochaenidae in Porites. Carter (1978) mentioned in his study of Atlantic gastrochaenids the specialization of this family for survival in thin and rapidly eroded substrata and also their ability to exclude gastropod predations. The amount of degradation apportioned to boring bivalves varies considerably in the literature. Highsmith et al. (1983) found that $3.3 \%$ of the bored area of Montastrea cavernosa on the 
Reef Barrier of Belize was due to Bivalvia. Hein \& Risk (1975) estimated them to be responsible for $15 \%$ of damage in Florida corals. Trudgill (1976) measured a boring rate of $0.9 \mathrm{~cm} \mathrm{yr}^{-i}$ for Lithophaga in Aldabra (Indian Ocean) limestone.

The 2 chitons Cryptoplax striatus and Acanthochiton zelandicus are grazing species which are particularly abundant on Tulear reefs at the mid-littoral level. Taylor \& Way (1976) estimated that on Aldabra atoll erosional activities of chitons are responsible for the loss of $40 \mathrm{~g} \mathrm{~m}^{-2}$ of $\mathrm{CaCO}_{3}$ per year.

Other grazers which play an important role in the biological destruction of coral reefs are echinoids. Regis \& Thomassin (1982), working on a coral reef at Tuléar, found that the echinoids Echinometra mathaei and Echinostrephus mollaris are abundant in places with strong currents. These 2 species dominated samples from residual pools where strong tidal movement occurs. Russo (1980) calculated an erosion rate of $0.04 \mathrm{~kg} \mathrm{CaCO}_{3} \mathrm{yr}^{-1}$ by one specimen of E. mathaei at Enewetak (W Pacific). Hughes \& Keij (1973), in the Persian Gulf, calculated a rate of $0.18 \mathrm{~kg}$ ind..$^{-1} \mathrm{yr}^{-1}$ for urchins. Bak (pers. comm.) found $0.1 \mathrm{~kg}$ ind ${ }^{-1} \mathrm{yr}^{-1}$ on Moorea Reef (Polynesia).

On Tuléar reefs vermetids Dendropoma sp. are particularly abundant on megablocks in undamaged Porites.

The cirriped Lithrotrya valentiana is also a species occurring at high level on Tuléar reefs. Trudgill (1976) estimated an erosion rate of $0.8 \mathrm{~cm}$ ind. $\mathrm{yr}^{-1}$ in Aldabra atoll. Arh \& Stanton (1973) considered this organism as an indicator of the intertidal or near-intertidal environment and reported an average density of 1 tube $\mathrm{cm}^{-2}$ of rock in the beach rock of Cayo Icacos (Puerto Rico).

Unfortunately, it has not been possible to calculate rates of bioerosion for the habitats at Tuléar using published rates obtained elsewhere because of the methods of calculation used: rates of boring activity vary according to habitat and locality. In this work only the environmental factors are correlated with bioerosion patterns. Recently, Sammarco et al. (1987), in their analysis of the effect of grazing and damselfish territoriality on internal bioerosion of dead corals, showed a shift in the taxonomic composition when grazing pressure varies. It is very difficult to give detailed results of macroborer distribution because there are many factors occurring at different levels and different scales which may or may not act in synergy.

The major findings in this study may be summarized as follows:

(1) The borer organism assemblage on Tuléar reef flats is quite homogeneous throughout the infralittoral biotopes.

(2) Local environmental factors affect the abundance of some species: localities with high flow energy are characterized by Cryptoplax striatus; in biotopes with long immersion times, boring Mytilidae and particularly Lithophaga hanleyana, as well as echinoids, predominate.

(3) The borer assemblages appear not to be correlated with type of coral.

(4) The presence of calcareous algae results in a decrease of the number of boring species and individuals.

(5) In the mid-littoral zone the boring community is characterized by Lithotrya valentiana, Dendropoma sp. and Aspidosiphon ochrus.

Acknowledgements. We thank the following people for identifying fauna: Drs P. Kaas and E. Leloup (chitons), Drs E. B. and N. J. Cutler (sipunculans) and Dr G. Richard (molluscs). We thank Dr P. Hutchings, Dr R. Bak, D. von Siebenthal and anonymous reviewers for reading and critizing this manuscript. We thank Dr J. P. Reys and C. Bernard for their help in mathematical treatments

\section{LITERATURE CITED}

Arh, W. M. Stanton, R. J. (1973). The sedimentologic and paleoecologic significance of Lithotrya, a rock-borings barnacle. J. sedim. Petrol. 43 (1): 20-23

Arnaud, P., Thomassin, B. (1986). Habits and morphological adaptation of mytilids (Mollusca: Bivalvia) from coastal and reefal environments in south west Malagasia (Indian Ocean). 9th int. Malacol. Congr Edinburgh, in press

Bak, R. P. M. (1985). Recruitment patterns and mass mortalities in the sea urchin Diadema antillarum. Proc. 5th int. Coral Reef Symp. 5: 267-272

Battistini, R. and 23 co-authors (1975). Eléments de terminologie récifale Indo-Pacifique. Téthys 7 (1): 1-111

Benzecri, J. P. and collaborators (1973). L'analyse des données, Vol. 2. Dunod, Paris

Bromley, R. G. (1978). Bioerosion of Bermuda reefs. Paleogeogr Paleoclimatol. Paleontology 18: 725-739

Carter, J. G. (1978). Ecology and evolution of the Gastrochaenacea (Mollusca, Bivalvia) with notes on the evolution of the endolithic habit. Bull. Peabody Mus. nat. Hist. 41: 1-92

Clausade, M. (1971). Répartition qualitative et quantitative des Polychètes vivant dans les alvéoles des constructions organogènes épirécifales de la portion septentrionale du Grand Récif de Tuléar Rec. Trav. Stn mar. Endoume, suppl. 10: 259-270

Crossland, C. (1903). The fauna and geography of the Maldive and Laccadive archipelagos. Cambridge Univ. Press, Cambridge

Cutler, E. B., Cutler, N. J. (1979). Madagascar and Indian Ocean Sipuncula. Bull. Mus. Hist. nat., Paris 4 ème sér. 1 (sec. $\mathrm{A} \mathrm{n}^{\circ} 4$ ) : 941-990

Davies, P. J., Hutchings, P. A. (1983). Initial colonization, erosion and accretion on coral substrate: experimental results. Lizard Island, Great Barrier Reef. Coral Reefs 2: 27-35

Ebbs, N. K. (1966). The coral inhibiting polychaetes of the northern florida reef tract. Part. 1 Aphroditidae, Polynoidae, Amphinomidae, Eunicidae and Lysaretidae. Bull. mar. Sci. Gulf Caribb. 16: 485-554

Faure, G. (1982). Recherche sur les peuplements de Scléractiniaires des récifs coralliens de l'Archipel des Mascareig- 
nes (Océan Indien occıdental). Thèse Doc. ès Sci., Univ. Aix-Marseille II

Harmelin-Vivien, M. L. (1979). Ichtyofaune des récifs coralliens de Tuléar (Madagascar): écologie et relations trophiques. Thèse Doc. ès Sci., Univ. Aix-Marseille II

Harmelin-Vivien, M. L., Peyrot-Clausade, M., Thomassin B. A. Vasseur, P. (1982). Biocénoses des récifs coralliens de la région de Tuléar ( $\mathrm{S}$. W de Madagascar). Résultats synthétiques. C.r. Acad. Sci., Paris, 295 sér. III: 791-796

Hein, F. J., Risk, M. J. (1975). Bioerosion of coral heads: inner patch reefs, Florida reef tract. Bull. mar. Sci. 25: 133-138

Highsmith, R. C., Lueptow, R. L., Shonberg, S. C. (1983). Growth and bioerosion of three massive corals on the Belize Barrier reef. Mar. Ecol. Prog. Ser. 13: 261-271

Hill, M. O. (1974). Correspondence analysis: a neglected multivariate method. Appl. Statist. 23: 340-354

Hughes, M. W., Keij, A. J. (1973). Organisms as producers of carbonate sediment and indicators of environment in the Southern Persian Gulf. In: Purser, B. H. (ed.) The Persian Gulf. Springer-Verlag, New York, p. 33-56

Hutchings, P. A. (1986). Biological destruction of coral reefs. A review. Coral Reefs 4: 239-252

Kleeman, K. H. (1984). Lithophaga (Bivalvia) from dead coral from the Great Barrier Reef, Australia. J. mollusc. Stud. 50: $192-230$

Montaggioni, L. (1978). Recherches géologiques sur les complexes récifaux de l'archipel des Mascareignes (Océan Indien Occidental). Thèse Doc. ès Sci., Univ. Aix-Marseille II

Morton, B. C. (1983). Coral-associated bivalves of the IndoPacific. The Mollusca 6: 139-223

Naim, O. (1988). Distributional patterns of mobile fauna associated with Halimeda on the Tiahura coral reef complex (Moorea, French Polynesia). Coral Reefs 6 (3/4): $237-250$

Peyrot-Clausade, M. (1977). Faune cavitaire mobile des platiers coralliens de la région de Tuléar (Madagascar). Thèse Doc. ès Sci., Univ. Aix-Marseille Ir

Picard, J (1967). Essai de classement des grands types de peuplements marins benthiques tropicaux d'après les observations effectuées dans les parages de Tuléar (SudOuest de Madagascar). Rec. Trav. Stn mar. Endoume (fasc hors série), suppl. 6: 3-24

Pichon, M. (1978). Recherches sur les peuplements à domi-

This article was presented by Dr R. P. M. Bak, Texel, The Netherlands nance d'Anthozoaires dans les récifs coralliens de Tuléar (Madagascar). Atoll Res. Bull. 222: 1-447

Regis, M. B., Thomassin, B. A. (1982). Ecologie des Echinoïdes réguliers dans les récifs coralliens de la région de Tuléar (SW de Madagascar). Adaptation de la microstructure des piquants. Ann. Inst. océanogr. Paris 58 (2): 117-158

Rice, M. E., Macintyre, I. G. (1982). Distribution of Sipuncula in the coral reef community, Carrie Bow Cay, Belize. In Rützler, K., MacIntyre I. G. (eds). The Atlantic Barrier Reef ecosystem at Carrie Bow Cay, Belize. I. Structure and communities. Smithsonian Institution Press, Washington, p. 311-320

Russo, A. R. (1980). Bioerosion by two rock-boring echinoids (Echinometra mathaei and Echinostrephus aciculatus) on Enewetak atoll, Marshall Islands. J. mar. Res. 18: 99-110

Sammarco, P. W., Risk, M. J., Rose, C. (1987). Effects of grazing and damselfish territoriality on internal bioerosion of dead corals: indirect effects. J. exp. mar. Biol. Ecol. 112: $185-199$

Scott, P. J. B. (1980). Associations between scleractinians and coral-boring molluscs in Hong Kong. In: Morton, B. S. (ed.) Proc. 1st int. Workshop on the Malacofauna of Hong Kong and Southern China, Hong Kong 1977. Hong Kong Univ. Press, Hong Kong, p. 121-128

Shannon, C. E., Weaver, W. (1963). The mathematical theory of communication. Illinois Univ. Press, Urbana

Soliman, G. N. (1969). Ecological aspects of some coral-boring gastropods and bivalves of the north-western Red-Sea Am. Zool. 9: 887-984

Taylor, J. D., Way, K. (1976). Erosive activities of chitons at Aldabra atoll. J. sedim. Petrol. 46 (4): 974-977

Thomassin, B. A. (1978). Les peuplements de sédiments coralliens de la région de Tuléar (SW de Madagascar). Leur insertion dans le contexte cottier indo-pacifique. Thèse Doc. ès Sci., Univ. Aix-Marseille II

Trudgill, S. T (1976). The marine erosion of limestone on Aldabra atoll, Indian Ocean. Z. Geomorph. (suppl.) 26: $164-200$

Vasseur, P. (1981). Recherches sur les peuplements sciaphiles des récifs coralliens de la région de Tuléar ( $\mathrm{SW}$ de Madagascar). Thèse Doc. ès Sci., Univ. Aix-Marseille

Wilson, B. R. (1979). A revision of Queensland lithophagine mussels (Bivalvia, Mytilidae, Lithophaginae) Rec. Aust. Mus. 32 (13): 435-489

Manuscript first received: June 20,1988

Revised version accepted: November 28, 1989 